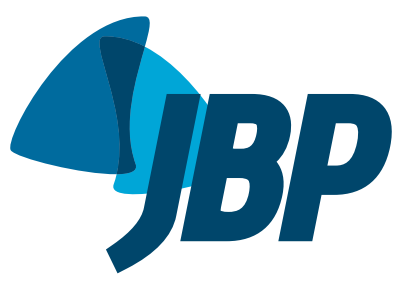

1. Universidade Federal de Minas Gerais Belo Horizonte (MG) Brasil.

2. Secretaria de Estado de Saúde de Minas Gerais, Belo Horizonte (MG) Brasil.

3. Programa Acadêmico em Tuberculose Faculdade de Medicina, Universidade Federal do Rio de Janeiro, Rio de Janeiro (RJ) Brasil.

4. Departamento de Farmácia Social, Faculdade de Farmácia, Universidade Federal de Minas Gerais, Belo Horizonte (MG) Brasil.

5. Departamento de Clínica Médica, Faculdade de Medicina, Universidade Federal de Minas Gerais, Belo Horizonte (MG) Brasil.

Submitted: 29 January 2016

Accepted: 31 July 2016.

Study carried out at the Universidade de Minas Gerais, Belo Horizonte (MG) Brasil.

\section{Prevalence of latent Mycobacterium tuberculosis infection in prisoners}

\author{
Pedro Daibert de Navarro',2, Isabela Neves de Almeida', Afrânio Lineu Kritski ${ }^{3}$, \\ Maria das Graças Ceccato ${ }^{4}$, Mônica Maria Delgado Maciel', \\ Wânia da Silva Carvalho ${ }^{4}$, Silvana Spindola de Miranda ${ }^{5}$
}

\begin{abstract}
Objective: To determine the prevalence of and the factors associated with latent Mycobacterium tuberculosis infection (LTBI) in prisoners in the state of Minas Gerais, Brazil. Methods: This was a cross-sectional cohort study conducted in two prisons in Minas Gerais. Tuberculin skin tests were performed in the individuals who agreed to participate in the study. Results: A total of 1,120 individuals were selected for inclusion in this study. The prevalence of LTBI was $25.2 \%$. In the multivariate analysis, LTBI was associated with self-reported contact with active tuberculosis patients within prisons (adjusted OR $=1.51 ; 95 \% \mathbf{C l}: 1.05-2.18$ ) and use of inhaled drugs (adjusted OR = $1.48 ; 95 \% \mathbf{C l}: 1.03-2.13)$. Respiratory symptoms were identified in $131(11.7 \%)$ of the participants. Serological testing for HIV was performed in 940 (83.9\%) of the participants, and the result was positive in $5(0.5 \%)$. Two cases of active tuberculosis were identified during the study period. Conclusions: Within the prisons under study, the prevalence of LTBI was high. In addition, LTBI was associated with self-reported contact with active tuberculosis patients and with the use of inhaled drugs. Our findings demonstrate that it is necessary to improve the conditions in prisons, as well as to introduce strategies, such as chest X-ray screening, in order to detect tuberculosis cases and, consequently, reduce M. tuberculosis infection within the prison system.
\end{abstract}

Keywords: Prisons; Tuberculin test; Latent tuberculosis, HIV.

\section{INTRODUCTION}

It is estimated that there were 9.4 million new cases of tuberculosis worldwide in $2014,12 \%$ of which were HIV-infected, as well as 1.5 million tuberculosis-related deaths. ${ }^{(1)}$ Brazil is one of the 22 countries that collectively account for $80.0 \%$ of the global burden of this disease.(1) Minas Gerais ranks fourth among the states with the highest number of tuberculosis cases in Brazil.(2) The main global strategy for tuberculosis control, proposed by the World Health Organization (WHO) and known as Stop $\mathrm{TB}^{(1)}$ highlights, in one of its components, the need to promote tuberculosis control activities targeting prisoners because such individuals are at high risk for latent Mycobacterium tuberculosis infection (LTBI) and for developing tuberculosis disease, given that this a serious public health problem in penal institutions. ${ }^{(3-6)}$

The presence of tuberculosis within the prison system has been described as a threat. Some authors have suggested that it will not be possible to control tuberculosis in the community unless effective measures are taken to combat the disease in prisons. In those places, tuberculosis is not limited to prisoners only, because it also affects the community with which they interact, family members, and prison staff, during and after incarceration. ${ }^{(3,5-9)}$ In Brazil, the incidence of tuberculosis within the prison system is 28-fold higher than that in the general population. ${ }^{(10)}$ The prevalence of LTBI is also high in those places, ${ }^{(5,7-9,11-13)}$ a reality that remains unknown in most Brazilian regions since there are no studies on the subject.

Identifying LTBI in prisoners should be given priority so that preventive measures can be adopted, especially in groups with conditions associated with high risks of developing tuberculosis, such as HIV seropositivity, diabetes mellitus, chronic renal failure, use of immunosuppressants, etc. ${ }^{(6,9,14)}$ The method for identifying suspected tuberculosis cases should be decided upon on a scenario-by-scenario basis, depending on the local context and the existing resources. ${ }^{(3,8,9,15-17)}$ The main screening strategies are based on symptoms, chest X-ray, and the tuberculin skin test (TST). ${ }^{(3,8,9,14,15)}$ Each has advantages and limitations. ${ }^{(3,8,9,15-18)}$ Active surveillance for cases of tuberculosis disease, through screening, should be undertaken not only upon entry into the prison system, but also afterwards. The purpose of this surveillance is to examine individuals who are more likely to develop the disease, such as those with respiratory symptoms (RS), identify active cases, and treat them accordingly. Such measures break the chain of transmission and decrease the incidence of the disease. ${ }^{(6,11,18)}$ The objective of the present study was to estimate the prevalence of and the

Correspondence to:

Silvana Spíndola de Miranda. Avenida Professor Alfredo Balena, 190, Santa Efigênia, CEP 30130-100, Belo Horizonte, MG, Brasil.

Tel.: 5531 3409-9905 or 5531 98821-7283. E-mail: silvanaspindola@gmail.com

Financial support: This study received financial support from the Fundação de Amparo à Pesquisa do Estado de Minas Gerais (FAPEMIG, Foundation for the Support of Research in the State of Minas Gerais; Process nos. APQ 03266-13 and APQ 00094-12), the Brazilian Conselho Nacional de Desenvolvimento Cientifico e Tecnológico (CNPq, National Council for Scientific and Technological Development; Process nos. CNPq 446796/2014 and 310174/2014-7), and the Minas Gerais State Departments of Social Defense and Health. 
factors associated with LTBI in prisoners in the main prison area in Minas Gerais.

\section{METHODS}

\section{Study design}

This was a cross-sectional cohort study conducted in the two largest prisons (condemned prisoners) in the main prison area in the state of Minas Gerais, both of which are located in the city of Ribeirão das Neves and house $8.4 \%$ of the prisoners in the state. A total of 1,492 inmates were included in the present study $(67.0 \%$ of the prisoners in the prisons under study and $5.8 \%$ of the prisoners in the state) $)^{(19-21)}$ between April and June of 2013. The eligibility criteria were as follows: having had no previous treatment for tuberculosis; having no tuberculosis disease at the study outset; and having never undergone a TST.

\section{Administering and reading TSTS}

TSTs were performed by the Mantoux method, which consists of administration of $0.1 \mathrm{~mL}$ ( 2 tuberculin units) of M. tuberculosis PPD RT23 (State Serum Institute, Copenhagen, Denmark) on the left forearm. TSTs were read $72 \mathrm{~h}$ after being administered, by measuring the maximum transverse diameter of induration with a millimeter ruler. An induration of $\geq 10 \mathrm{~mm}$ was considered a positive result for HIV-uninfected individuals, whereas an induration of $\geq 5 \mathrm{~mm}$ was considered a positive result for HIV-infected individuals. ${ }^{(14)}$ Isoniazid preventive therapy was recommended to all prisoners at risk for developing active tuberculosis. ${ }^{(6)}$ All TSTs were administered and read by trained and certified professionals for research project participation.

\section{Sampling and bacteriological tests}

Sputum samples were collected from individuals with a history of cough, regardless of length of history, for smear microscopy and mycobacterial culture. Drug susceptibility testing was performed if culture was positive, in accordance with the WHO laboratory guidelines.

\section{Serological testing for HIV}

Serological testing for HIV was offered to all participants, along with pre- and post-test counseling. ${ }^{(22)}$ Positive results by ELIZA were confirmed by the Western Blot method.

\section{Data collection}

Educational and awareness-raising activities regarding $M$. tuberculosis infection were developed for the prison health team and the prisoners. The study participants completed a questionnaire addressing sociodemographic characteristics (age, gender, marital status, schooling, occupation before incarceration, and length of incarceration); behavioral characteristics (use of licit and illicit drugs, alcoholism-assessed by the Cut down, Annoyed, Guilty, and Eye-opener screening questionnaire-(23) smoking, and contact with active pulmonary tuberculosis patients inside or outside prison); health history (previous treatment for active tuberculosis, BCG vaccination, HIV infection, presence of diabetes mellitus or other diseases, and use of medications); and symptoms suggestive of pulmonary tuberculosis (cough, cough duration, expectoration, hemoptysis, fever, adynamia, cyanosis, anorexia, weight loss, and night sweats). The health records available in the prisons were consulted to fill in missing information.

\section{Statistical analysis}

The selected characteristics were analyzed descriptively by gender, with results being presented as frequencies, and by univariate and multivariate analysis, with results being presented as measures of central tendency and dispersion. The mean differences for continuous variables were compared using the Student's t-test, whereas the proportions of categorical variables were compared using Pearson's chi-square test. The IBM SPSS Statistics software package, version 21.0 (IBM Corporation, Armonk, NY, USA) was used for statistical analysis, and the data were recorded in tables. The magnitude of the association between the selected explanatory variables and the event of interest, that is, LTBI, was estimated by calculating ORs with $95 \%$ CIs. Variables with a $p$ value of $\leq 0.25$ in univariate analysis, as determined by the Wald test, were manually selected to build a multivariate model via a stepwise regression selection procedure. The significance level required for inclusion in the final model containing the selected variables was set at 0.05 to adjust for potential confounders properly. Only the variables showing a significant independent association with the event of interest remained in the final model. The likelihood ratio test was used to compare the models. The goodness of fit of the final models was assessed using the Hosmer-Lemeshow test.

\section{Ethical guidelines}

The study was approved by the Research Ethics Committee of the Federal University of Minas Gerais (Protocol no. 0617.0.203.000-09) on April 5, 2010.

\section{RESULTS}

\section{Characteristics of the population}

Most of the prisoners agreed to participate in the study ( $N=1,431 ; 96.0 \%)$, and, of those, 1,120 $(78.0 \%)$ were included in the final sample. Of the total number of individuals excluded from the study ( $\mathrm{n}=$ $311), 68(21.8 \%)$ had undergone a TST previously, whereas $243(78.1 \%)$ had not because of previous tuberculosis $(35 / 243 ; 14.4 \%)$, tuberculosis treatment $(4 / 243 ; 1.6 \%)$, transfer to another prison $(13 / 243$; $5.3 \%)$, or refusal $(191 / 243 ; 78.6 \%$; Figure 1$)$.

In the study population (Table 1), the mean age was $29 \pm 7$ years and most individuals had had less than 7 years of schooling $(90.0 \%)$. The length of incarceration was longer than 12 months for $57.0 \%$ 
of the participants (mean, $28 \pm 25$ months). Contact with active pulmonary tuberculosis patients occurred outside and inside prison, respectively, in $10.0 \%$ and $15.0 \%$ of the cases. The proportions of smoking and pre-incarceration alcoholism were, respectively, $61.1 \%$ and $24.8 \%$. The use of illicit drugs was reported by $75.0 \%$ of the inmates. Of those, $97.0 \%$ reported using inhaled drugs, $2.0 \%$ reported using injected drugs, and $1.0 \%$ reported using inhaled and injected drugs.

Diabetes mellitus, chronic renal failure, silicosis, and use of immunosuppressive medications were reported, respectively, by $1.2 \%, 0.7 \%, 0.1 \%$, and $2.9 \%$ of the prisoners. Serological testing for HIV was performed in $83.9 \%$, and the result was positive in $0.5 \%$.

In the univariate analysis, LTBI was found to be associated with the following variables: gender; marital status; contact with active tuberculosis patients outside prison; pre-incarceration alcoholism; use of inhaled illicit drugs; diabetes mellitus; chronic renal failure; and chronic use of corticosteroids and/or immunosuppressants (Tables 1 and 2).

\section{Prevalence of and factors associated with LTBI}

The prevalence of LTBI was $25.2 \%$. In the multivariate analysis, the occurrence of LTBI was associated with self-reported contact with active tuberculosis patients inside prison (adjusted OR $=1.51 ; 95 \% \mathrm{CI}: 1.05-2.18$ ) and with the use of inhaled drugs (adjusted OR = 1.48; 95\% CI: 1.03-2.13; Table 2). The results of the TSTs were negative for all individuals who tested positive for HIV.

\section{Measures of frequency of symptoms suggestive of tuberculosis infection and of tuberculosis disease}

At least one of the symptoms suggestive of tuberculosis (cough, weight loss, loss of appetite, and chest pain) were reported by $68.0 \%$ of the study population. Cough and weight loss were the most common symptoms, occurring in $27.0 \%$ and $25.0 \%$ of the participants, respectively. Of those who reported cough, $43.0 \%$ had had the symptom for two weeks or more, corresponding to 131 individuals of the total number of prisoners (11.7\%). Two cases were diagnosed with tuberculosis, and the strains were susceptible to rifampin, streptomycin, isoniazid, and ethambutol.

\section{DISCUSSION}

The magnitude of LTBI within the Brazilian prison system, as previously mentioned, remains mostly unknown. The prevalence observed in this study (25.2\%) was higher than those reported for prisons in countries such as the USA $(17.0 \%){ }^{(24)}$ Australia

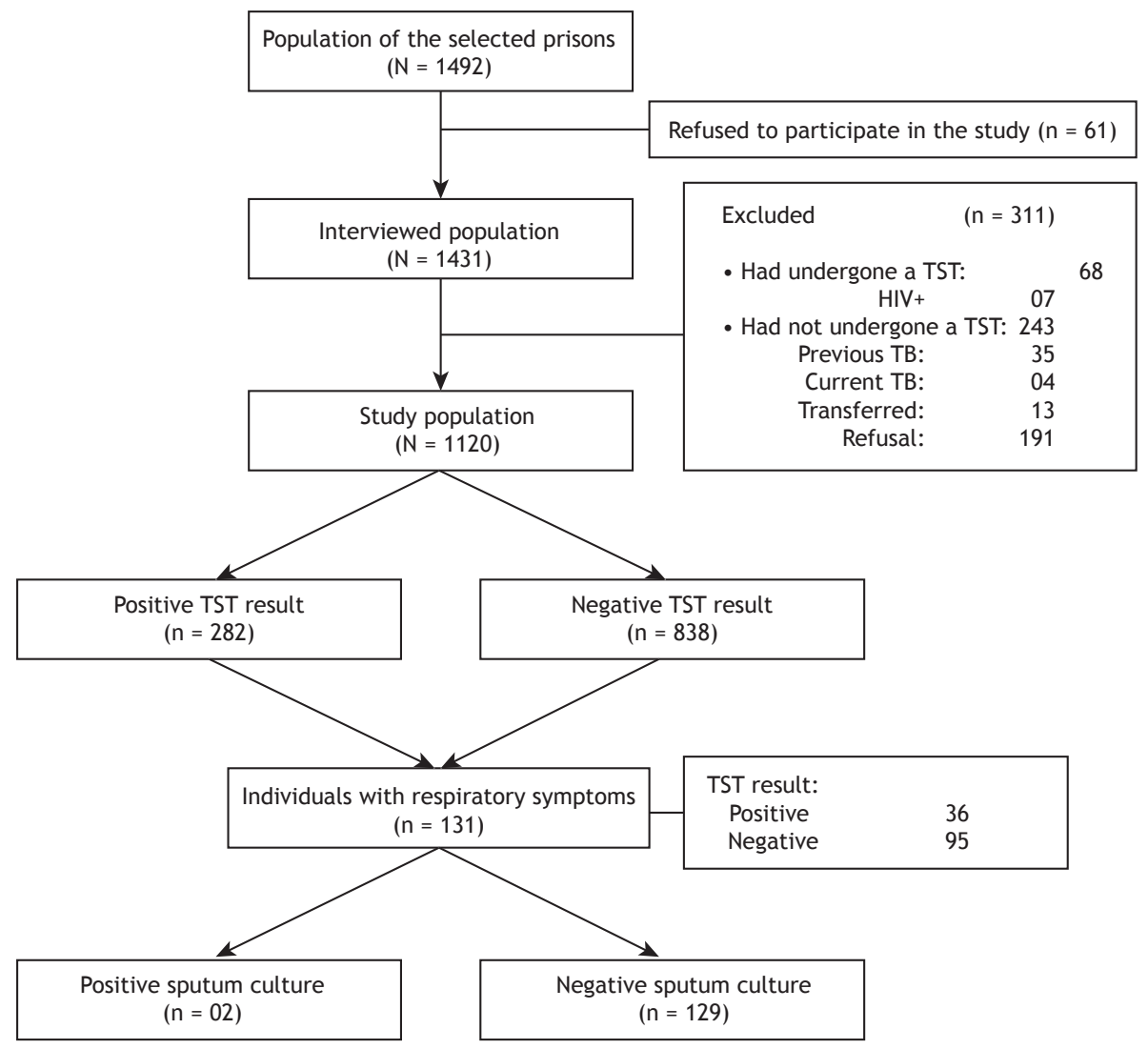

Figure 1. Individuals selected for inclusion in the study, Minas Gerais, $2013(\mathrm{~N}=1,120)$. TST: tuberculin skin test; and TB: tuberculosis. 
Table 1. Descriptive characteristics of the sample of prisoners under study, by gender, Minas Gerais, Brazil, 2013 (N $=1,120){ }^{a}$

\begin{tabular}{|c|c|c|c|}
\hline \multirow[t]{2}{*}{ Characteristics } & \multicolumn{2}{|c|}{ Gender } & \multirow[t]{2}{*}{$\mathbf{p}$} \\
\hline & Female & Male & \\
\hline \multicolumn{4}{|l|}{ Sociodemographic characteristics } \\
\hline Age, years & & & 0.165 \\
\hline$<30$ & $53(53.0)$ & $608(60.1)$ & \\
\hline$\geq 30$ & $47(47.0)$ & $403(39.9)$ & \\
\hline Marital status & & & $<0.001$ \\
\hline Single & $80(80.0)$ & $584(57.3)$ & \\
\hline Married/steady partner & $20(20.0)$ & $436(40.7)$ & \\
\hline Schooling, years & & & 0.089 \\
\hline$<7$ & $85(85.0)$ & $920(90.4)$ & \\
\hline$\geq 7$ & $15(15.0)$ & $98(9.6)$ & \\
\hline Occupation before incarceration & & & 0.714 \\
\hline Yes & $93(93.0)$ & $938(92.0)$ & \\
\hline No & $7(7.0)$ & $82(8.0)$ & \\
\hline Length of incarceration, months & & & 0.389 \\
\hline$\leq 15$ & $55(55.0)$ & $515(50.9)$ & \\
\hline$>15$ & $45(45.0)$ & $505(49.5)$ & \\
\hline \multicolumn{4}{|l|}{ Behavioral characteristics } \\
\hline Contact with active TB patients outside prison & & & $<0.001$ \\
\hline Yes & $24(24.0)$ & $83(8.1)$ & \\
\hline No & $62(62.0)$ & $850(84.1)$ & \\
\hline Does not know & $14(14.0)$ & $87(16.8)$ & \\
\hline Contact with active TB patients inside prison & & & 0.054 \\
\hline Yes & $7(7.0)$ & $162(15.9)$ & \\
\hline No & $70(70.0)$ & 754 (73.9) & \\
\hline Does not know & $23(23.0)$ & $104(10.2)$ & \\
\hline Pre-incarceration alcoholism & & & 0.047 \\
\hline Yes & $33(33.0)$ & $245(24.0)$ & \\
\hline No & $67(67.0)$ & $775(76.0)$ & \\
\hline Smoking & & & 0.203 \\
\hline Yes & $67(67.0)$ & $617(60.5)$ & \\
\hline No & $33(33.0)$ & 403 (39.5) & \\
\hline Use of inhaled drugs & & & $<0.001$ \\
\hline Yes & $49(49.0)$ & 789 (77.4) & \\
\hline No & $51(51.0)$ & $231(22.6)$ & \\
\hline Use of injected drugs & & & 0.511 \\
\hline Yes & $3(3.0)$ & $27(2.6)$ & \\
\hline No & $97(97.0)$ & $993(97.4)$ & \\
\hline \multicolumn{4}{|l|}{ Health history } \\
\hline Diabetes mellitus & & & 0.031 \\
\hline Yes & $4(4.4)$ & $9(1.1)$ & \\
\hline No & $86(95.6)$ & $815(98.9)$ & \\
\hline Chronic renal failure & & & 0.027 \\
\hline Yes & $3(3.1)$ & $5(0.5)$ & \\
\hline No & $95(96.9)$ & $1002(99.5)$ & \\
\hline Chronic use of corticosteroids and/or immunosuppressants & & & 0.004 \\
\hline Yes & $8(8.2)$ & $25(2.4)$ & \\
\hline No & $89(91.8)$ & $993(97.6)$ & \\
\hline Presence of at least one symptom suggestive of $\mathrm{TB}^{\mathrm{b}}$ & & & 0.113 \\
\hline Yes & $75(75.0)$ & $686(67.3)$ & \\
\hline No & $25(25.0)$ & $334(32.7)$ & \\
\hline Individuals with respiratory symptoms ${ }^{c}$ & & & 0.126 \\
\hline Yes & $7(7.0)$ & $124(12.2)$ & \\
\hline No & $93(93.0)$ & $896(87.8)$ & \\
\hline
\end{tabular}

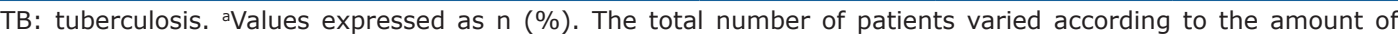
ignored information. 'bough, expectoration, hemoptysis, dyspnea, chest pain, cyanosis, fever, asthenia, night sweats, recent weight loss, and loss of appetite. 'Individuals with cough for two weeks or more. 
Table 2. Univariate and multivariate analyses of factors associated with latent Mycobacterium tuberculosis infection in the study population, Minas Gerais, Brazil, $2014(\mathrm{~N}=1,120)$. $^{\mathrm{a}}$

\begin{tabular}{|c|c|c|c|c|c|c|}
\hline \multirow[t]{2}{*}{ Factors } & \multicolumn{2}{|c|}{ LTBI } & \multicolumn{2}{|c|}{ Univariate analysis } & \multicolumn{2}{|c|}{ Multivariate analysis* } \\
\hline & $\begin{array}{c}\text { Yes } \\
n(\%)\end{array}$ & $\begin{array}{c}\text { No } \\
\text { n (\%) }\end{array}$ & p & OR (95\% CI) & p & aOR $(95 \% \mathrm{CI})$ \\
\hline Sociodemographic facto & & & & & & \\
\hline $\begin{array}{l}\text { Gender } \\
\text { Female } \\
\text { Male }\end{array}$ & $\begin{array}{c}26(26.0) \\
256(25.1)\end{array}$ & $\begin{array}{c}74(74.0) \\
764(77.9)\end{array}$ & 0.843 & $\begin{array}{c}1 \\
0.954(0.597-1.524)\end{array}$ & $-\cdots$ & $-\cdots-\cdot$ \\
\hline $\begin{array}{l}\text { Age, years } \\
\quad<30 \\
\geq 30\end{array}$ & $\begin{array}{l}166(25.1) \\
114(25.3)\end{array}$ & $\begin{array}{l}495(74.9) \\
336(74.7)\end{array}$ & 0.934 & $\begin{array}{c}1 \\
1.012(0.768-1.333)\end{array}$ & $-\cdots-\cdot$ & $-\cdots-\cdot$ \\
\hline $\begin{array}{l}\text { Marital status } \\
\text { Married/steady partner } \\
\text { Single }\end{array}$ & $\begin{array}{l}108(23.7) \\
174(26.2)\end{array}$ & $\begin{array}{l}348(76.3) \\
490(73.8)\end{array}$ & 0.340 & $\begin{array}{c}1 \\
1.144(0.868-1.509)\end{array}$ & $\cdots-\cdot$ & $-\cdots$ \\
\hline $\begin{array}{l}\text { Schooling, years } \\
\quad \geq 7 \\
\quad<7\end{array}$ & $\begin{array}{l}24(21.2) \\
258(25.7)\end{array}$ & $\begin{array}{l}89(78.8) \\
747(74.3)\end{array}$ & 0.305 & $\begin{array}{c}1 \\
1.281(0.798-2.054)\end{array}$ & $-\cdots$ & $-\cdots$ \\
\hline $\begin{array}{l}\text { Occupation before } \\
\text { incarceration } \\
\text { Yes } \\
\text { No }\end{array}$ & $\begin{array}{c}260(25.2) \\
22(24.7)\end{array}$ & $\begin{array}{l}771(74.8) \\
67(75.3)\end{array}$ & 0.917 & $\begin{array}{c}1 \\
0.974(0.590-1.608)\end{array}$ & --.-- & $-\cdots$ \\
\hline $\begin{array}{l}\text { Length of incarceration, } \\
\text { months } \\
<15 \\
\geq 15\end{array}$ & $\begin{array}{l}135(23.7) \\
147(26.7)\end{array}$ & $\begin{array}{l}435(76.3) \\
403(73.3)\end{array}$ & 0.241 & $1.175(0.897-1.540)$ & 0.543 & $1.096(0.816-1.471)$ \\
\hline
\end{tabular}

\section{Behavioral factors}

Contact with active TB patients

outside prison

$\begin{array}{cccc}230(25.2) & 682(74.8) & 0.672 & 1 \\ 29(27.1) & 78(72.9) & & 1.102(0.702-1.732)\end{array}$

No

Yes

Contact with active TB patients

inside prison

$193(23.4) \quad 631(76.6) \quad 0.030$

No

$53(31.4) \quad 116(68.4)$

1

$1 \quad 0.026 \quad 1.516(1.052-2.185)$

Yes

Alcoholism

No

$209(24.8) \quad 633(75.2) \quad 0.632$

Yes

Smoking

No

$73(26.3) \quad 205(73.7)$

$1.079(0.791-1.470)$

Yes

$98(22.5) \quad 338(77.5) \quad 0.097$

$184(26.9) \quad 500(73.1)$

1

$0.207 \quad 1.221(0.896-1.666)$

Use of inhaled drugs

No

Yes

$\begin{array}{cccccc}61(21.6) & 221(78.4) & 0.111 & 1 & 0.034 & 1.483(1.031-2.133) \\ 221(26.4) & 617(73.6) & & 1.307(0.940-1.817) & & \end{array}$

Use of injected drugs

$\begin{array}{llllcll}\text { No } & 273(25.0) & 817(75.0) & 0.286 & 1 & 0.072 & 2.249(0.931-5.430)\end{array}$

Yes

$9(30.0) \quad 21(70.0)$

$1.574(0.684-3.621)$

\section{Health history}

Diabetes mellitus

\begin{tabular}{lcccc}
$\quad$ No & $215(23.9)$ & $686(76.1)$ & 0.947 & 1 \\
$\quad$ Yes & $3(23.1)$ & $10(76.9)$ & & $0.957(0.261-3.510)$ \\
Chronic renal failure & & & & \\
$\quad$ No & $273(24.9)$ & $824(75.1)$ & 0.418 & 1 \\
$\quad$ Yes & $3(37.5)$ & $5(62.5)$ & & $1.811(0.430-7.627)$ \\
Use of immunosuppressants & & & & \\
$\quad$ No & $275(25.4)$ & $807(74.6)$ & 0.395 & 1 \\
$\quad$ Yes & $6(18.8)$ & $26(81.2)$ & & $0.677(0.276-1.663)$ \\
HIV infection & & & & \\
$\quad$ No & $233(24.9)$ & $702(75.1)$ & $\cdots . .-$ & $\ldots$ \\
Yes & $0(0.0)$ & $5(100.0)$ & & \\
\hline
\end{tabular}

LTBI: latent Mycobacterium tuberculosis infection; TB: tuberculosis; and aOR: adjusted OR. ${ }^{a}$ The total number of patients varied according to the amount of ignored information. ${ }^{*}$ Hosmer-Lemeshow test; $X^{2}=0.679$; degrees of freedom $=2 ; p=0.712$. 
$(14.0 \%),{ }^{(25)}$ and Italy $(17.9 \%),{ }^{(26)}$ and in the state of Mato Grosso do Sul, Brazil (20.8\%). ${ }^{(13)}$ However, it was lower than those found in Spain $(40.3 \%)^{(27)}$ and Switzerland (46.9\%), ${ }^{(28)}$ and in other states in Brazil (Bahia, Mato Grosso do Sul, and São Paulo; range, 30.9-61.5\%).(29-31) These differences highlight the need for studying LTBI in different regions. There have been no studies showing the prevalence of LTBI in the region where the prisons selected for this study are located. In addition, the results of the present study are important not only to Minas Gerais, but also to other regions in Brazil where the prisons have the same scenarios.

Although there has been considerable debate about the use of the TST in places where there is mass vaccination with BCG, the WHO suggests the use of this test to detect LTBI in places where the TST is recommended, especially in adults. In the present study, $89.2 \%$ of the participants had been vaccinated more than 10 years prior (mean, 30 years). Therefore, BCG vaccination probably contributed little to TST positivity, because the response to the TST is nearly nonexistent 8-10 years after vaccination. ${ }^{(32,33)}$ The TST may yield false-negative results in people who live with HIV and are not receiving antiretroviral therapy, because the response to the TST is based on the immune response of the individual ${ }^{(14)}$; this is probably the reason why LTBI was not identified in the prisoners recently diagnosed with HIV infection.

Several factors create a favorable context for increasing the prevalence of LTBI in prisoners. ${ }^{(11,30,34)}$ As discussed, this population consists predominantly of young adults from socioeconomically disadvantaged communities with high rates of active tuberculosis. Among other elements posing an increased risk for the development of tuberculosis, the rate of alcoholism $(24.8 \%)$ was lower than that reported in other studies $(39.2-44.1 \%){ }^{\left({ }^{30}\right)}$ whereas the rate of smoking $(61.1 \%)$ was similar. ${ }^{(30)}$ The use of inhaled illicit drugs (97.0\%) was higher than that reported by other authors (25.2$45.2 \%)$, whereas the use of injected illicit drugs (2.0\%) was lower (7.5-13.1\%). ${ }^{(27)}$

The rate of HIV infection found in our study sample $(0.5 \%)$ was similar to the mean estimated rate for the Brazilian population $(0.4 \%)^{(35)}$; however, it was lower than those reported by other authors (1.0$11.3 \%) .(18,27,34,36)$ Therefore, it is important to detect LTBI in the HIV-infected population so that preventive measures can be taken, because HIV-infected individuals with LTBI have an 8.0-10.0\% annual risk of developing active tuberculosis, as do users of inhaled illicit drugs with LTBI. In contrast, HIV-uninfected individuals with LTBI have a $10.0 \%$ lifetime risk of developing tuberculosis. ${ }^{(18,37)}$

In the prisons selected for this study, treatment of LTBI was not given to prisoners with diabetes mellitus, those with chronic renal failure, or those receiving immunosuppressants, although preventive therapy is recommended for these groups, which are considered at high risk for developing tuberculosis. $(6,9,14)$
Chief among the conditions of the prison environment that can favor the spread of the disease are limited exposure to sunlight, ${ }^{(5,6)}$ overpopulation, ${ }^{(5,6,8,18,30,34)}$ and inadequate ventilation. ${ }^{(5,6,30)}$ To this context, we can add lack of training in tuberculosis control activities among prison health teams ${ }^{(5)}$ and limited access to health care in prisons. ${ }^{(30,34)}$ Therefore, changes should be made to the physical structures of prisons, and training in tuberculosis control should be provided to prison health teams.

In the present study, the likelihood of LTBI was found to be increased when the prisoners reported contact with someone with tuberculosis disease, a finding that has also been observed by several authors. ${ }^{(3,13,34)}$ This might indicate an increased perception by the prisoners of the health risk related to the disease, since there is a high frequency of tuberculosis in the environment. (38) $^{2}$ There was an association between the use of inhaled illicit drugs and LTBI, but no association was found between smoking and LTBI; the use of inhaled illicit drugs probably leads to greater tissue damage and greater impairment of mucociliary activity, which is the body's first line of protection when the bacilli enter the airways. ${ }^{(39)}$

The expected rate of individuals with RS in Brazil is $1.0 \%$ in the general population. ${ }^{(6)}$ Among the prisoners included in this study, the proportion of individuals with RS was found to be 11.7-fold higher than that in the general population; however, it was lower than those reported in other studies conducted in Brazil (20.6-36.1\%). ${ }^{(13,30,34)}$ This can be explained by the poor infrastructural conditions in the prisons and by the high rates of smoking and use of inhaled illicit drugs.

There is no consensus in the scientific literature regarding an ideal mechanism for identification of people who are more likely to develop tuberculosis among prisoners. ${ }^{(5,6,9,15,16)}$ However, the identification of chronic cough is used as a screening tool. $(15,16,36)$ Some authors have reported that this symptom alone is not relevant to raising a suspicion of tuberculosis in this population. ${ }^{(38)}$ Surveillance for cases of pulmonary tuberculosis should preferably include a combination of symptoms (fever, weight loss, and asthenia, for instance) rather than consider chronic cough alone. ${ }^{(30,40)}$ The symptom approach is the only screening tool available in most resource-poor settings. ${ }^{(5,6,8,15-18)}$ In addition, symptoms suggestive of tuberculosis may be nonspecific where there are high rates of other conditions associated with respiratory diseases, such as smoking. ${ }^{(8)}$

Minas Gerais, despite having the second largest overall population in the country, has the fourth lowest incidence rate of tuberculosis. It is possible that the prevalence rates of LTBI and active tuberculosis for the prisons selected for this study are not as high as those reported for other prisons because of the local epidemiological context.

One of the limitations of the present study is the fact that data on exposure and outcome were collected at the same time, which makes it difficult to understand 
the temporal relationship between them and provides a static view of the dimension of the problem. Another limitation was that the incidence rates of LTBI and tuberculosis disease were not evaluated.

In conclusion, the prevalence of LTBI was high among the prisoners of the two largest prisons in Minas Gerais, as well as being associated with self-reported contact with active tuberculosis patients inside prison and with the use of inhaled drugs. Our findings demonstrate that it is necessary to improve the conditions in prisons, as well as to introduce strategies, such as chest X-ray screening, in order to detect tuberculosis cases and, consequently, reduce $M$. tuberculosis infection within the prison system.

\section{ACKNOWLEDGMENTS}

The authors would like to thank the members of the Group of Research on Mycobacterial Diseases and the staff of the Mycobacterial Research Laboratory of the Federal University of Minas Gerais School of Medicine. The authors are also grateful to the staff of the Central Laboratory of Public Health of the state of Minas Gerais/ Octávio Magalhães Institute/Fundação Ezequiel Dias (FUNED, Ezequiel Dias Foundation). In addition, the authors would like to thank the Minas Gerais State Departments of Health and Social Defense and the Graduate Program in Adult Health of the Federal University of Minas Gerais School of Medicine.

\section{REFERENCES}

1. World Health Organization. Global tuberculosis report 2015. Geneva: World Health Organization; 2015

2. Brasil. Ministério da Saúde. Portal da Saúde [homepage on the Internet]. Brasília: Ministério da Saúde [cited 2013 Jan 31]. Programa Nacional de Controle da Tuberculose: Apresentação Padrão. Available from: http://portal.saude.gov.br/portal/saude/profissional/ area.cfm?id_area $=1527$

3. Organización Panamericana de la Salud (OPS). Plan Regional de Tuberculosis 2006-2015. Washington, DC: OPS; 2006.

4. World Health Organization. Working together with businesses guidance on TB and TB/HIV prevention, diagnosis, treatment and care in the workplace. Geneva: World Health Organization; 2012.

5. Organización Panamericana de la Salud (OPS). Guía para el control de la tuberculosis en poblaciones privadas de libertad de América Latina y el Caribe. Washington, DC: OPS; 2008.

6. Ministério da Saúde. Secretaria de Vigilância em Saúde. Departamento de Vigilância Epidemiológica. Manual de recomendações para o controle da tuberculose no Brasil. Brasília: Ministério da Saúde; 2011.

7. Baussano I, Williams BG, Nunn P, Beggiato M, Fedeli U, Scano F. Tuberculosis incidence in prisons: a systematic review. PLoS Med. 2010;7(12):e1000381. http://dx.doi.org/10.1371/journal. pmed. 1000381

8. Bone A, Aerts A, Grzemska M, Kimerling M, Kluge H, Levy M, et al Tuberculosis control in prisons; a manual for programme managers. Geneva: World Health Organization; 2000.

9. Centers for Disease Control and Prevention (CDC); National Center for HIVIAIDS, Viral Hepatitis, STD, and TB Prevention. Prevention and control of tuberculosis in correctional and detention facilities: recommendations from CDC. Endorsed by the Advisory Council for the Elimination of Tuberculosis, the National Commission on Correctional Health Care, and the American Correctional Association. MMWR Recomm Rep. 2006;55(RR-9):1-44.

10. Brasil. Ministério da Saúde. Portal da Saúde [homepage on the Internet]. Brasília: Ministério da Saúde [cited 2015 Dec 8]. Programa Nacional de Controle da Tuberculose: Apresentação Padrão. Available from: http://portal.saude.gov.br/index.php/o-ministerio/ principal/743-secretaria-svs

11. Aerts A, Habouzit M, Mschiladze L, Malakmadze N, Sadradze N, Menteshashvili $O$, et al. Pulmonary tuberculosis in prisons of the ex-USSR state Georgia: results of a nation-wide prevalence survey among sentenced inmates. Int J Tuberc Lung Dis. 2000;4(12):1104 10

12. Nogueira PA, Abrahão RM. Tuberculosis infection and the length of stay of County Jails prisoners in the western sector of the city of São Paulo. Rev Bras Epidemiol. 2009;12(1):30-8. http://dx.doi. org/10.1590/S1415-790X2009000100004

13. Carbone Ada S, Paião DS, Sgarbi RV, Lemos EF, Cazanti RF, Ota $\mathrm{MM}$, et al. Active and latent tuberculosis in Brazilian correctional facilities: a cross-sectional study. BMC Infect Dis. 2015;15:24. http:// dx.doi.org/10.1186/s12879-015-0764-8

14. Targeted tuberculin testing and treatment of latent tuberculosis infection. This official statement of the American Thoracic Society was adopted by the ATS Board of Directors, July 1999. This is a Joint Statement of the American Thoracic Society (ATS) and the Centers for Disease Control and Prevention (CDC). This statement was endorsed by the Council of the Infectious Diseases Society of America. (IDSA), September 1999, and the sections of this statement. Am J Respir Crit Care Med. 2000;161(4 Pt 2):S221-47.

15. Lönnroth K, Corbett E, Golub J, Godfrey-Faussett P, Uplekar M, Weil D, et al. Systematic screening for active tuberculosis: rationale, definitions and key considerations. Int J Tuberc Lung Dis. 2013;17(3):289-98. http://dx.doi.org/10.5588/ijtld.12.0797

16. Golub JE, Mohan $\mathrm{Cl}$, Comstock GW, Chaisson RE. Active case finding of tuberculosis: historical perspective and future prospects. Int J Tuberc Lung Dis. 2005;9(11):1183-203.

17. Legrand J, Sanchez A, Le Pont F, Camacho L, Larouze B. Modeling the impact of tuberculosis control strategies in highly endemic overcrowded prisons. PLoS One. 2008;3(5):e2100. http://dx.doi. org/10.1371/journal.pone.0002100

18. Kendig N. Tuberculosis control in prisons. Int $\mathrm{J}$ Tuberc Lung Dis. 1998;2(9 Suppl 1):S57-S63.

19. Brasil. Ministério da Justiça. Departamento Penitenciário Nacional Levantamento nacional de informações penitenciárias. Brasília: Ministério da Justiça; 2014. p. 17-21

20. Ministério Público do Estado de Minas Gerais. [homepage on the Internet]. Belo Horizonte: o Ministério [cited $2016 \mathrm{Apr} 1$ ]. Presídio Dutra Ladeira está proibido de receber novos presos até regularizar superlotação. Available from: https://www.mpmg. $\mathrm{mp}$.br/comunicacao/noticias/presidio-dutra-ladeira-esta-proibido-dereceber-novos-presos-ate-regularizar-superlotacao.htm.V777m_krLIV

21. Freitas CR. O cárcere feminino: do surgimento às recentes modificações introduzidas pela lei de execução penal. Rev Fac Arnaldo Janssen Direito. 2014;4(4):125-45

22. Ministério da Saúde. Instrução Normativa n. 1.626, de 10 de julho de 2007. Regulamenta os procedimentos e condutas para a abordagem consentida a usuários que procuram os serviços de saúde com vistas a realizar testes de HIV e outras DST, bem como aos que não comparecem ao tratamento já em curso. Brasília: Diário Oficial da União; 2007.

23. Mayfield D, McLeod G, Hall P. The CAGE questionnaire: validation of a new alcoholism screening instrument. Am J Psychiatry. 1974;131(10):1121-3.

24. Lobato MN, Leary LS, Simone PM. Treatment for latent TB in correctional facilities: a challenge for TB elimination. Am J Prev Med. 2003;24(3):249-53. http://dx.doi.org/10.1016/S0749-3797(02)005834

25. Levy MH, Butler TG, Zhou J. Prevalence of Mantoux positivity and annual risk of infection for tuberculosis in New South Wales prisoners, 1996 and 2001. N S W Public Health Bull. 2007;18(78):119-24. http://dx.doi.org/10.1071/NB07051

26. Carbonara S, Babudieri S, Longo B, Starnini G, Monarca R, Brunetti B, et al. Correlates of Mycobacterium tuberculosis infection in a prison population. Eur Respir J. 2005;25(6):1070-6. http://dx.doi.org/10.118 3/09031936.05.00098104

27. Marco A, Solé N, Orcau A, Escribano M, del Baño L, Quintero S, et al. Prevalence of latent tuberculosis in inmates recently incarcerated in a men's prison in Barcelona. Int J Tuberc Lung Dis. 2012;16(1):60-4. http://dx.doi.org/10.5588/ijtld.11.0007

28. Ritter C, Elger BS. Prevalence of positive tuberculosis skin tests 
during 5 years of screening in a Swiss remand prison. Int J Tuberc Lung Dis. 2012;16(1):65-9. http://dx.doi.org/10.5588/ijtld.11.0159

29. Ferreira MM, Ferrazoli L, Palaci M, Salles PS, Medeiros LA, Novoa $P$, et al. Tuberculosis and HIV infection among female inmates in São Paulo, Brazil: a prospective cohort study. J Acquir Immune Defic Syndr Hum Retrovirol. 1996;13(2):177-83. http://dx.doi. org/10.1097/00042560-199610010-00009

30. Lemos AC, Matos ED, Bittencourt CN. Prevalence of active and latent TB among inmates in a prison hospital in Bahia, Brazil. J Bras Pneumol. 2009;35(1):63-8. http://dx.doi.org/10.1590/S180637132009000100009

31. Estevan AO, Oliveira SM, Croda J. Active and latent tuberculosis in prisoners in the Central-West Region of Brazil. Rev Soc Bras Med Trop. 2013;46(4):515-8. http://dx.doi.org/10.1590/0037-8682-14412013

32. Menzies D, Gardiner G, Farhat M, Greenaway C, Pai M. Thinking in three dimensions: a web-based algorithm to aid the interpretation of tuberculin skin test results. Int J Tuberc Lung Dis. 2008;12(5):498505.

33. Ruffino-Netto A. Interpretation of the tuberculin test [Article in Portuguese]. Rev Saude Publica. 2006;40(3):546-7. http://dx.doi. org/10.1590/S0034-89102006000300026

34. Kuhleis D, Ribeiro AW, Costa ER, Cafrune PI, Schmid KB, Costa $\mathrm{LL}$, et al. Tuberculosis in a southern Brazilian prison. Mem Inst
Oswaldo Cruz. 2012;107(7):909-15. http://dx.doi.org/10.1590/S007402762012000700012

35. Ministério da Saúde. Secretaria de Vigilância em Saúde. Departamento de DST, Aids e Hepatites Virais. Boletim Epidemiológico Aids e DST. Brasilia: o Ministério; 2013.

36. Reichard AA, Lobato MN, Roberts CA, Bazerman LB, Hammett TM Assessment of tuberculosis screening and management practices of large jail systems. Public Health Rep. 2003;118(6):500-7. http:// dx.doi.org/10.1016/S0033-3549(04)50286-8

37. Smieja MJ, Marchetti CA, Cook DJ, Smaill FM. Isoniazid for preventing tuberculosis in non-HIV infected persons. Cochrane Database Syst Rev. 2000;(2):CD001363

38. Diuana V, Lhuilier D, Sánchez AR, Amado G, Araújo L, Duarte AM, et al. Health in the prison system: representations and practices by prison guards in Rio de Janeiro, Brazil [Article in Portuguese]. Cad Saude Publica. 2008;24(8):1887-96. http://dx.doi.org/10.1590/S0102 $311 \times 2008000800017$

39. Rich AR, editor. The Pathogenesis of Tuberculosis. Springfield: Charles C. Thomas Publisher; 1944

40. Cain KP, McCarthy KD, Heilig CM, Monkongdee P, Tasaneeyapan T, Kanara $\mathrm{N}$, et al. An algorithm for tuberculosis screening and diagnosis in people with HIV. N Engl J Med. 2010;362(8):707-16. http://dx.doi. org/10.1056/NEJMoa0907488 